\title{
Kistik Fibrozis ile İlişkili Diyabet: Bir Olgu Sunumu
}

\author{
Cystic Fibrosis Related Diabetes: A Case Report
}

\section{Rukiye Bozbulut ${ }^{1}$, Esra Döğer ${ }^{2}$, Tuğba Şişmanlar Eyüboğlu³ ${ }^{3}$ Zekiye Küpçü ${ }^{4}$, Aysun Bideci', Orhun Çamurdan ${ }^{6}$, Peyami Cinaz ${ }^{7}$ Ayşe Tana Aslan ${ }^{8}$}

Geliş tarihi/Received: 29.04.2020 • Kabul tarihi/Accepted: 29.06 .2020

\section{ÖZET}

Kistik fibrozis ile ilişkili diyabet (KFID), kistik fibrozisin (KF) yaygın bir komplikasyonudur. Kistik fibrozis ile ilişkili diyabetin temel nedeni hastalarda yıllar içerisinde pankreas hasarının artması ile beraber pankreas adacık hücrelerinin kaybı ve insülin eksikliğinin gelişmesidir. Tedavideki amaç çocuk ve adolesanlarda normal büyüme ve gelişmenin ve kan glukoz regülasyonunun sağlanmasıdır. Tedavinin temelini insülin tedavisi ve tıbbi beslenme tedavisi oluşturur. İnsülin tedavisi, KFİD hastalarında akciğer fonksiyonunu stabilize eder ve beslenme durumunu iyileştirir. Kistik fibrozis ile ilişkili diyabetli hastalara yüksek enerji, yüksek yağ ve yüksek tuz içeren bir beslenme planı önerilmektedir. Karbonhidrat sayımı, insülin tedavisi alan hastalarda öğün öncesi insülin dozunun belirlenmesinde yararlıdır. Bu yazıda kliniğimizde izlenen KFİD’li bir çocuk olgunun medikal ve tıbbi beslenme tedavisi literatür derlemesi eşliğinde sunulmuştur.

Anahtar kelimeler: Kistik fibrozis ile ilişkili diyabet, insülin tedavisi, tıbbi beslenme tedavisi

\begin{abstract}
Cystic fibrosis-related diabetes (CFRD) is a common complication of cystic fibrosis (CF). The main reason for CFRD is the increase of pancreatic damage in patients over the years, as well as the loss of pancreatic islet cells and the development of insulin deficiency. The purpose of treatment is to ensure normal growth and development in children and adolescents and to regulate blood glucose. The basis of the treatment is insulin therapy and medical nutrition therapy. Insulin therapy stabilizes lung function and improves nutritional status in patients with CFRD. A diet with high energy, high fat and high salt is recommended for patients with CFRD. Carbohydrate counting is useful in determining the pre-meal insulin dose in patients receiving insulin therapy. In this article, medical and medical nutritional therapy of the patient with CFRD, followed in our clinic, is presented with a review of the literature.
\end{abstract}

Keywords: Cystic fibrosis-related diabetes, insulin therapy, medical nutrition therapy

1. İletişim/Correspondence: Gazi Üniversitesi Sağllk Araştırma ve Uygulama Merkezi, Pediatrik Endokrinoloji Bilim Dalı, Ankara, Türkiye

E-posta: dyt_rukiye@hotmail.com • @ https://orcid.org/0000-0003-4317-9226

2. Gazi Üniversitesi Sağllk Araştırma ve Uygulama Merkezi, Çocuk Endokrinoloji Bilim Dall, Ankara, Türkiye • •

3. Gazi Üniversitesi Sağlık Araştırma ve Uygulama Merkezi, Çocuk Göğüs Hastalıkları Bilim Dalı, Ankara, Türkiye • • ำ https://orcid.org/0000-0001-7284-4999

4. Gazi Üniversitesi Sağlık Araştırma ve Uygulama Merkezi, Çocuk Endokrinoloji Bilim Dall, Ankara, Türkiye • ๑ https://orcid.org/0000-0001-7979-5456
5. Gazi Üniversitesi Sağlık Araştırma ve Uygulama Merkezi, Çocuk Endokrinoloji Bilim Dalı, Ankara, Türkiye • ๑ https://orcid.org/0000-0003-0302-414X

6. Gazi Üniversitesi Sağllk Araştırma ve Uygulama Merkezi, Çocuk Endokrinoloji Bilim Dall, Ankara, Türkiye • ๑ https://orcid.org/0000-0003-1368-2605

7. Gazi Üniversitesi Sağllk Araştırma ve Uygulama Merkezi, Çocuk Endokrinoloji Bilim Dall, Ankara, Türkiye - ๑ https://orcid.org/0000-0001-5942-1852

8. Gazi Üniversitesi Sağlık Araştırma ve Uygulama Merkezi, Çocuk Göğüs Hastalıkları Bilim Dall, Ankara, Türkiye • ๑ https://orcid.org/0000-0002-5360-8517 


\section{GíRiş}

Kistik fibrozis (KF), ekzokrin salgı bezlerinde yer alan Kistik Fibrozis Transmembran Regülatör (KFTR) proteinini kodlayan gendeki otozomal resesif mutasyonlar sonucu klor kanallarının etkilenmesi ile ortaya çıkan ve başta solunum ve gastrointestinal sistem olmak üzere, tüm vücudu etkileyen multisistemik bir hastalıktır (1). Dünya genelindeki sıklığı 1/2500 canlı doğumdur (2). Kistik fibroziste ekzokrin kanallar, koyu mukus tarafindan tıkanır. Bunun sonucunda, solunum sisteminde kronik bakteriyel enfeksiyonlar ve inflamasyon sonucu gelişen hava yolu obstrüksiyonu ve gastrointestinal sistemde malabsorpsiyona neden olan pankreas ve safra yolları tıkanıklığı görülür. Pankreasta, önce ekzokrin işlevlerde bozulmanın sonucunda malabsorpsiyon gelişmekte, sonra endokrin adacık hücreleri zarar görmekte; insülin eksikliği ve diyabet ortaya çıkmaktadır (3). Kistik fibrozis ile ilişkili diyabet (KFID), KF'de en sık görülen komplikasyondur (4). Kistik fibrozis ile ilişkili diyabet bebeklik dâhil her yaşta ortaya çıkabilmekte, yaşam süresinin uzaması ile beraber KFİD sıklığı artış göstermektedir (2). Kistik fibrozis ile ilişkili diyabet hem insülin sekresyonunun azaldığı hem de insülin direncinin arttığı bir hastalık sürecidir $(2,4)$. Kistik fibrozis ile ilişkili diyabet ile tip 1 ve tip 2 diyabet arasında önemli patofizyolojik farklılıklar vardır (Tablo 1) (2).

Tablo 1. Kistik fibrozis ile ilişkili diyabetin tip 1ve tip 2 diyabetle karşılaştırılması (2)

\begin{tabular}{lccc}
\hline & Tip 1 DM & Tip 2 DM & KFID \\
\hline Prevalans & $\% 0.2$ & $\% 11$ & \%35 \\
En yüksek başlangıç yaşı & Çocuklar ve gençler & Erişkinler & $18-24$ yaş \\
Vücut ağırlı̆̆ına göre değerlendirme & Normal & Obez & Normal/Zaylf \\
Otoimmün etiyoloji & Evet & Haylr & Hayır \\
İnsülin sekresyonu & Azalmış & Rölatif azalmış & Azalmış \\
İnsülin duyarlılı̆̆ı & Azalmış & Çok azalmış & Azalmış \\
Keton & Evet & Nadir & Nadir \\
Tedavi & İnsülin & Diyet, oral ilaçlar, insülin & İnsülin \\
Mikrovasküler komplikasyonlar & Evet & Evet & Evet \\
Makrovasküler komplikasyonlar & Evet & Evet & Hayır \\
Metabolik sendrom & Hayır & Evet & Hayır \\
Ölüm nedeni & Kardiyovasküler & Kardiyovasküler & Pulmoner \\
\hline
\end{tabular}

Kistik fibrozis ile ilişkili diyabet, hem çocuklarda hem de yetişkinlerde önemli ölçüde artmış morbidite ve mortalite ile ilişkilidir. Ancak son 15 yıl içinde erken tanı ve tedavi KFİD ile ilişkili mortalitede önemli ölçüde azalma sağlanmıştır $(3,5)$. Hastalık alevlenmelerinde artan insülin direnci, glukokortikoid uygulamaları, artan enerji gereksinimi yüksek karbonhidrat alımına ve sık besin tüketimine neden olarak hiperglisemi sıklığını artırırken, glukagon eksikliği, enerji harcamasında artış, değişen gastrointestinal motilite ve emilim KFİD’in yönetimini karmaşık hale getirmekte ve tedavide güçlükler oluşturmaktadır $(2,6)$. Kistik fibrozis ile ilişkili diyabet tedavisinin hedefleri hipergliseminin katabolik etkilerini önlemek, beslenme durumunu ve beden kütle indeksini (BKİ) iyileştirmek ve hipoglisemiyi en aza indirirken pulmoner alevlenmelerin sıklığını azaltmaktır (6). Bu nedenle KFİ'li hastalar diyabet ve kistik fibrozis konusunda uzman olan multidisipliner bir ekip tarafından izlenmelidir (7).

$\mathrm{Bu}$ olgu sunumunda KFİD tanısı alan olgunun medikal ve tıbbi beslenme tedavisinin yönetimi tartışılmıştır. 


\section{OLGU SUNUMU}

On yaşında kız olgu, KF nedeniyle Çocuk Göğüs Hastalıkları Polikliniği'ndeki rutin kontrollünde kan glukoz yüksekliği saptanması nedeni ile Çocuk Endokrinoloji Polikliniği'ne başvurmuştur. Sistem sorgusunda poliüri, polidipsi, polifaji, vücut ağırlık kaybı, enürezis noktürna gibi diyabet semptomları bulunmamıştır. Özgeçmişinde 7 aylıkken tekrarlayan akciğer enfeksiyonu nedeni ile Çocuk Göğüs Hastalıkları Polikliniği'nde ter testinin $133 \mathrm{mmol} / \mathrm{L}$ (normal $<60 \mathrm{mmol} / \mathrm{L}$ ) ve kistik fibrozis gen analizinde c.1521_1523delCTT (DelF508) ve c.3909C > G (N1303K) bileşik heterozigot mutasyon saptanarak KF tanısı aldığ 1 öğrenilmiştir. Olgu solunum sistemine yönelik düzenli gögüs fizyoterapisi, inhale dornaz alfa tedavisi ve eşlik eden pankreatik yetmezliğine yönelik pankreatik enzim replasman tedavisi, oral tuz desteği ve multivitamin desteği almaktadır. Fizik muayenede vücut ağırlığının $32 \mathrm{~kg}$ (25-50. persentil [per.]), boy uzunluğunun $143 \mathrm{~cm}$ (75. per.), BKİ= 15.6 $\mathrm{kg} / \mathrm{m}^{2}$ (-0.74 SD-Z skor), pubertede (Tanner evre 2), çomak parmak deformitesinin olduğu, diğer sistem muayenelerinin normal olduğu gözlenmiştir. İlk muayene sirasında bakılan rastlantısal kan glukozu $248 \mathrm{mg} / \mathrm{dL}$ bulunmuştur. Yapılan laboratuvar incelemesinde açlık kan glukozu 116 mg/dL (60$100 \mathrm{mg} / \mathrm{dL}$ ), kan ketonu negatif, C peptid düzeyi 3.2 ng/mL (0.9-7.1 ng/mL), HbA1c düzeyinin \%9, diğer biyokimyasal parametrelerin, karaciğer ve böbrek fonksiyon testlerinin de normal aralıklarda olduğu saptanmıştır Bu dönemde yapılan solunum fonksiyon testinde hafif küçük havayolu obstrüksiyonu (FEV1=\%100, FVC=\%111， MEF25-75=\%73 FEV1/ FVC:84) ${ }^{1}$ bulunmuştur. Kistik fibrozis ile ilişkili diyabet tanısı ile kan glukoz regülasyonu amacıyla servise yatırılmıştır.

Olgunun hastanede yatış dönemindeki günlük enerji gereksinimi için önce bazal metabolizma hızı (BMH) (WHO denklemine göre) hesaplanmış, daha sonra fiziksel aktivite (1.4 katsayısı kullanılarak) ve büyüme-gelişme ekleri (1.9 $\mathrm{kkal} / \mathrm{kg} / \mathrm{gün}=60.8$ kkal/gün) yapılmıştır. Günlük enerji gereksinmesi normalin 1.2-1.5 katı olacak şekilde hesaplanmış ve $2200 \mathrm{kkal} / g u ̈ n ~ 3$ ana +3 ara öğünden oluşan tıbbi beslenme tedavisi düzenlenmiştir. Olgunun günlük enerji ihtiyacı \%45-50'si karbonhidratlardan, \%35-40'1 yağlardan, \%15’i proteinlerden karşılanacak şekilde düzenlenmiş ve $4 \mathrm{~g} / \mathrm{gün}$ oral tuz beslenme programına eklenmiştir. Olguya ve ailesine karbonhidrat sayımı eğitimi verilmiştir. Karbonhidrat sayımı eğitiminin birinci basamağında alınan karbonhidrat miktarını gram olarak sayma bilgi ve becerisi kazandırılmış, ana ve ara öğünlerde alması gereken karbonhidrat miktarı hesaplanmış, olguya sabah kahvaltısı, öğle ve akşam öğünlerinde 65'er gram, ara öğünlerde 20'şer gram karbonhidrat içeren menü planlanmış ve besin tüketim kaydı tutması istenmiştir. Kan glukoz izlemine göre $0.16 \mathrm{U} / \mathrm{kg} /$ gün dozunda subkutan insülin başlanmıştır. Günlük dozun \%40’ı uzun etkili (2 ünite), geri kalanı öğünlerde eşit şekilde paylaştırılarak (1'er ünite) hızlı etkili insülin tedavisi olarak verilmiştir. İzlemde besin tüketim kaydı alınan olguya öğünlerde tükettiği karbonhidrat miktarına göre insülin dozu hesaplama becerisi kazandırılmıştır. Karbonhidrat/ insülin (K/I) oranı (1 ünite insülin için gerekli karbonhidrat miktarı) 65/1, insülin duyarlılık faktörü $360 \mathrm{mg} / \mathrm{dL}$ (1 ünite insülinin azalttığı kan glukoz miktarı) olarak hesaplanmıştır.

Pankreatik yetmezliğine yönelik öğünlerden hemen önce oral pankreatik enzim replasman tedavisi (PERT) almaktadır. Kistik fibrozis tanısı koyulduğu dönemde PERT $2500 \mathrm{U} / \mathrm{kg} /$ gün lipaz şeklinde başlanmış ancak vücut ağırlığı kazanımı, günlük dışkılama sayısı ve gaita steatokrit sonucuna göre $6800 \mathrm{U} / \mathrm{kg} /$ güne kadar çıkılmıştır ve halen bu dozda almaktadır. Ana ve ara ögünlerde toplamda 9 kapsül/gün pankreatin tedavisi verilmiştir.

Olgunun yedi gün yatarak tedavi gördüğü süreçte yakın klinik ve laboratuvar izlemi ile tıbbi beslenme tedavisideğerlendirilmiştir. İlkikigünün besin tüketim kayıtları incelendiğinde olgunun sabah kahvaltısında 
önerilen enerji ve karbonhidrat miktarını karşılayamadığı gözlenmiş ve kahvaltı öğününe yağ içeriğinin \%50’si orta zincirli yağ asitlerinden (MCT) oluşan oligomerik enteral ürün eklenmiştir. Üçüncü günden itibaren beslenme programina uyumunun iyi olduğu ve günlük gereksinimlerini (yedi günlük ortalama enerji alımı $2141 \mathrm{kkal} /$ gün, ortalama karbonhidrat alım yüzdesi \%46, ortalama protein alım yüzdesi \%14.8, ortalama yağ alım yüzdesi \%39.2) karşlladığı görülmüştür. Hastanede yatış süresince kan glukoz izlemi yapılmıştır. İlk üç günün kan glukoz düzeyleri değerlendirildiğinde, açlık kan glukozu hedef aralıkta iken tokluk kan glukoz değerlerinin yüksek olması nedeniyle $\mathrm{K} / \mathrm{I}$ oranı her üç ana öğün için 43/1 olarak hesaplanmıştır. Sonraki üç günün kan glukoz düzeyleri değerlendirildiğinde, sabah-öğlen açlık ve sabah-akşam tokluk kan glukoz değerleri hedef aralıkta izlenirken, öğlen tokluk kan glukoz değerlerinin halen yüksek olması üzerine öğle öğününün K/İ oranı 33/1 olarak hesaplanmıştır. Akşam açlık kan glukoz düzeyleri genelde yüksek seyrettiği için bazal insülin dozunu artırmadan ikindi ara öğününde karbonhidrat alımı 20 g’dan 15 g’a indirilmiştir. Sabah ve akşam bolus dozlarında bir değişiklik yapılmamıştır. Olgunun taburcu olacağı gün $\mathrm{K} / \mathrm{I}$ oranları gözden geçirilerek kahvaltı öğününde $\mathrm{K} / \dot{\mathrm{I}}=43 / 1$, öğle öğününde $\mathrm{K} / \dot{\mathrm{I}}=33 / 1$, akşam öğününde $\mathrm{K} / \dot{\mathrm{I}}=43 / 1$ olacak şekilde ayarlanmıştır. Olgunun taburcu olduktan sonraki günlük enerji gereksinimi fiziksel aktivite düzeyindeki artış göz önünde bulundurularak tekrar hesaplanmıştır ve günlük enerji gereksinmesinin \%120'si olan 2400 kkal'lik 3 ana +3 ara öğünden oluşan tıbbi beslenme tedavisi programı düzenlenmiştir. Haftada $150 \mathrm{dk}$ orta yoğunlukta aerobik egzersiz (bisiklet sürme, yüzme, tenis, yavaş koşu, hızlı yürüyüşler, ip atlama vb.) yapması önerilmiştir. Olguya kan glukoz izlem defteri ve besin tüketim kayıt formlarını doldurup, bir hafta sonra polikliniğe gelmesi için randevu verilmiştir. Bir hafta sonra poliklinik kontrolünde olgunun açlık kan glukoz düzeylerinin 72-118 mg/dL, tokluk kan glukoz düzeylerinin 143-190 mg/dL arasında seyrettiği gözlenmiştir. Besin tüketim kayıtları incelendiğinde karbonhidrat sayımını doğru yaptığı, öğünlerde aldığı karbonhidrat miktarıyla insülin dozunu doğru eşleştirdiği görülmüştür. Günlük ortalama enerji alımı 2307 kkal/gün, ortalama karbonhidrat, yağ ve protein alım yüzdeleri ise sırasıyla enerjinin \%48.4'ü, \%37.4'ü ve \%14.2'si olarak hesaplanmıştır. Bazal insülin dozu ve $\mathrm{K} / \mathrm{I}$ oranları değiştirilmeyen olguya Çocuk Endokrinoloji ekibi tarafından üç ay sonrasına randevu verilmiştir. Olgunun üç ay sonra poliklinik kontrolünde, kan glukoz düzeylerinin regüle (açlık kan glukozu; 111-131 mg/dL, tokluk kan glukozu; 134$185 \mathrm{mg} / \mathrm{dL}$ ), tıbbi beslenme tedavisine uyumunun iyi, vücut ağırlığında $2.5 \mathrm{~kg}$ artış olduğu görülmüş ve HbA1c'sinin \%6.6 olduğu saptanmıştır. Son kontrolde yapilan solunum fonksiyon testi FEV1=\%105, $\mathrm{FVC}=\% 114$, MEF25-75=\%82 ve FEV1/FVC=88 olarak normal saptanmıştır.

$\mathrm{Bu}$ olgunun yazımı için hasta ve ailesinden yazllı onam alınmıştır.

\section{TARTIŞMA}

Kistik fibrozis ile ilişkili diyabet, kistik fibrozisin yaygın bir komplikasyonudur. Kistik fibrozisli hastalarda diyabet insidansı ve prevalansı diğer yaş gruplarına kıyasla daha yüksektir (2). Adolesan KF’li hastaların \%20'sinde ve erişkinlerin \%40-50'sinde KFİD bulunduğu rapor edilmiştir (7). Avrupa Kistik Fibrozis Epidemiyolojik Kayıtlarına (ERCF) göre ise KFİD prevalansının 10-14 yaş grubunda \%5, 15-19 yaş grubunda ise \%13 olduğu bildirilmektedir (8).

Ylllar içerisinde pankreas hasarının artması ile beraber hem insülin hem de glukagon eksikliğine yol açan toplam adacık kaybı, dalgalanan insülin direncine neden olan kronik ve akut inflamasyon, artan enerji harcaması ve emilim bozukluğu nedeniyle yüksek enerji gereksinimi, malnütrisyon riski, gecikmiş mide boşalması, değişmiş bağırsak motilitesi ve karaciğer hastalığı dahil olmak üzere bağırsak anormallikleri kistik fibrozise özgü glukoz metabolizmasını etkileyen etmenlerdir $(2,6)$. İnsülin eksikliği protein katabolizmasına, vücut ağırlığı kaybına ve solunum fonksiyonlarında azalmaya neden olmaktadır (4). Pulmoner fonksiyonlardaki azalma, 
KFİD tanısı almadan 2-6 yıl önce başlayabilmektedir $(4,9)$. Kistik fibrozisli hastalarda bozulmuş glukoz toleransı, 10'lu yaşlarda \%20, 30'lu yaşlarda ise \%82 oranında görülmektedir (10). Ayrıca etkilenen KFTR kanalının işlevini düzelten ve/veya güçlendiren yeni ilaç tedavileri vücut ağırlığı, beslenme durumunu, insülin duyarlılığı ve sekresyonunu etkileyebilir (6). Akut enfeksiyon ve glukokortikoid tedavisi sirasında insülin direnci artmaktadır. (3). Açıklanamayan poliürü, polidipsi, beslenme müdahalesine rağmen vücut ağırlığında azalma, büyüme hızında yavaşlama, gecikmiş puberte, solunum fonksiyonlarında açıklanamayan kronik düşüş KFİD’in semptomları arasındayken, bazı olgularda hiçbir belirti görülmeyebilir (2). Olgunun KFİD tanısı aldığı dönemde solunum fonksiyon testinde hafif küçük havayolu obstrüksiyonu saptanmışken, son kontrolde solunum fonksiyon testinin normal olduğu, düşüş saptanmadığı görülmüştür.

Kistik fibrozis ile ilişkili diyabet tanısı diyabetik oral glukoz tolerans testi veya açlık veya rastgele hiperglisemi varlığı ile doğrulanır (2,7). Erken KFID normal açlık glukoz düzeyleriyle karakterizedir, ancak zamanla açlık hiperglisemisi gelişebilir. Pulmoner ve enfeksiyon durumundaki akut değişikliklere bağlı olarak kan glukoz düzeylerinde dalgalanma görülebilir (2). Bu olguda iki veya daha fazla ölçümde rastgele ölçülen kan glukoz değerleri $200 \mathrm{mg} / \mathrm{dL}$ 'nin üstünde ve HbA1c değeri ise \%6.5’ten yüksek saptanmıştır.

İnsülin yetersizliği KFID’in birincil patolojik özelliğidir ve insülin replasmanı önerilen tek tıbbi tedavidir (2-4,6). Oral diyabetik ajanlar metabolik sonuçların iyileştirilmesinde insülin kadar etkili değildir ve KFID’de önerilmemektedir (2). İnsülin tedavisi KFİ'li hastalarda akciğer fonksiyonunu stabilize eder ve beslenme durumunu iyileştirir $(11,12)$. Diğer diyabet formlarında olduğu gibi insülin pompası veya uzun etkili bazal insülin ve hızlı etkili bolus insülin kombinasyonundan oluşan çoklu doz insülin uygulamaları en etkili insülin tedavisidir. Karbonhidrat sayımı yapan hastalar öğünde tüketecekleri karbonhidrat miktarı ve açlık kan glukoz düzeylerine göre öğün öncesi uygulayacakları hızlı etkili insülin dozunu hesaplama becerisi kazanırlar. Öğün öncesi açlık hiperglisemisi olan hastalarda uzun ve hızlı etkili (bazal-bolus) insülin tedavisi önerilirken, açlık hiperglisemisi olmayan hastalarda öğün öncesi hızlı etkili bolus insülin uygulaması yeterli olabilmektedir $(2,12)$. Bu olguda uygulanan esnek doz insülin tedavisi ile kan glukozu regüle edilip HbA1c düzeyinde düşme sağlanırken, vücut ağırlığında artış sağlanmıştır. Olgunun öğün öncesi ve sonrası kan glukoz sonuçlarının hedeflenen düzeylerde olduğu durumlarda alınan karbonhidrat miktarı yapılan insülin ünitesine bölünerek öğüne ait $\mathrm{K} / \mathrm{I}$ oranı belirlenebilir. Hesaplanan oranlarda gerektiğinde tokluk kan glukoz düzeyi hedeflerine göre artırma veya azaltma yapılarak ideal oran netleştirilir. Sabah, öğle ve akşam K/İ oranları farklılık gösterebilmektedir (13). Hastalığın akut alevlenmelerinin olmadığı ve kortikosteroid kullanımının gerekmediği durumlarda, endojen insülin sekresyonunun devam etmesi ve azalmış glukagon düzeyleri nedeniyle insülin gereksinmesi tip 1 diyabetli bireylerin balayı dönemlerinde olduğu gibi düşük miktardadır $(<0.5 \mathrm{U} /$ $\mathrm{kg} / \mathrm{gün}$ ). Kistik fibrozis ile ilişkili diyabet hastalarında akut enfeksiyon sirasında artan periferik insülin direnci nedeni ile insülin gereksinimi artmaktadır. Bu nedenle bu dönemde kan glukoz ölçümleri düzenli yapılıp insülin dozlarında gerekli artış sağlanmalı ve enfeksiyon düzeldikten sonra eski insülin dozlarına geri dönülmelidir (3). Bu olguya da düşük dozda insülin başlanmış ve kan glukoz düzeyi izlemlerine dayanarak gerekli değişiklikler yapılmıştır. Kistik fibrozis ile ilişkili diyabetlilerde kan glukoz düzeyi hedefleri, Amerika Diyabet Derneği’nin (ADA) diğer diyabetli bireyler için geliştirdikleri öneriler ile aynıdır. Ancak sık hipoglisemi yaşayan bireylerde bu öneriler esnetilip bireyselleştirilebilir (7). İnsülin tedavisi uygulayan KFID’li hastalarm günde en az üç kez kan glukoz düzeyini kontrol etmeleri gerekmektedir. Birçok hasta için öğün düzeni, egzersiz, gastroparezi gibi intestinal şikayetler ve akut sağlık durumuna bağlı olarak günde 4 ila 8 kez veya daha fazla kan glukoz izlemi yapılması önerilmektedir. Ayrıca bu hastalarda insülin dozu ayarlamada ve kan 
glukoz izleminde sürekli glukoz ölçüm sistemi (CGMS) kullanımı yararlı olabilmektedir (2).

Malnütrisyon, KF'de büyüme geriliği, pubertal gecikme, azalmış akciğer fonksiyonu ve erken ölüm ile ilişkilidir (4). Kistik fibrozis ile ilgili kllavuzlar diyabeti olanlar da dahil olmak üzere bütün KF'li olgularda yüksek enerji, yüksek yağ ve yüksek tuz içeren bir beslenme planını önermektedir $(2,13)$. Tıbbi beslenme tedavisindeki amaç, iyi bir beslenme durumu sağlamak ve sürdürmekle birlikte kan glukoz düzeylerini normal aralıkta tutmaktır (7). Kistik fibrozis ile ilişkili diyabetli olgular için oluşturulan beslenme önerileri, hem günlük gereksinmelerin farklı olması hem de kardiyovasküler hastalık risklerinin düşük olmasından dolayı tip 1 veya tip 2 diyabetli bireylerden çok farklıdır. Tip 1 ve tip 2 diyabette günlük enerji gereksinimi benzer yaş ve cinsiyetteki bireylerin enerji gereksinmesinin $\leq \% 100$ 'ü, yağ gereksinimi toplam enerjinin $<\% 35$ 'i, karbonhidrat gereksinimi toplam enerjinin $<\% 45-$ 60'l, protein gereksinimi toplam enerjinin $<\% 10-20$ 'si iken, KFİD’de günlük enerji gereksinimi benzer yaş ve cinsiyetteki bireylerin enerji gereksinmesinin \%120150'si (malnütrisyonu önlemek için), yağ gereksinimi toplam enerjinin <\%40'l, karbonhidrat gereksinimi toplam enerjinin <\%45-50'si, protein gereksinimi KF olmayan bir bireydeki referans alımının \%200'ü dür. Tip 1 ve tip 2 diyabette tuz alımı $\leq 6$ g/gün iken KFİD'de artan gereksinimden dolayı tuz tüketiminde sinırlama yapılmaz (2).

Artan enerji gereksinmesi ve malabsorbsiyonla olan kayıpları karşılamak, önerilen vücut ağırlığı ve boy uzunluğunu sağlamak için KF'li hastalara enerji kısıtlaması yapılmamalıdır (13). Enerji alımı arttıkça vücut ağırlığı kazanımı daha iyi olmaktadır. KF hastaların birçoğu önerilen yüksek enerji veya yağ alımını karşılamada zorlanabilmektedir. Bu hastaların tıbbi beslenme tedavileri gözden geçirilip gerekli durumlarda oral enteral destek tedavisine başlanmalıdır (3). Düşük glisemik indeksli besinlerin sindirim ve emilimleri daha yavaş olduğu için kan glukoz düzeylerinde ani azalma ve artmalar olmamakta ve daha iyi bir glisemik profil elde edilmektedir (14). Bu nedenle KFİD’li hastaların diyetlerinde glisemik indeksi düşük besinlerin yer alması sağlanmalıdır. Kistik fibrozis ile ilişkili diyabetli hastalarda karbonhidrat alımı sinırlandırılmasa da özellikle şekerli içecekler olmak üzere rafine edilmiş şeker tüketiminden kaçınılmalıdır (13).

İnsülin tedavisi alan KFİD hastaları için karbonhidrat sayımı, öğün öncesi insülin dozunun belirlenmesinde yararlıdır. Kistik fibrozis diyeti ile birlikte uygulanan karbonhidrat sayımı ve K/I oranlarının kullanılması glisemik kontrolün optimize edilmesine yardımcı olmaktadır (2,13). Karbonhidrat sayımı yöntemi KF’li olguların değişkenlik gösteren iştahları nedeni ile tüketebildikleri miktara göre insülin uygulamalarını sağlayıp, daha esnek bir yaşam tarzı sunmaktadır (3). $\mathrm{Bu}$ olguda karbonhidrat sayımı yöntemiyle besin seçiminde esneklik sağlanmış, tıbbi beslenme tedavisine uyumu artırmış, hastanın arzu ettiği yemek miktarına göre bolus insülin yapması sağlanarak kan glukoz düzeyleri regüle edilmiştir.

Özetle, sunulan KFİD olgusunda insülin tedavisi, enerji ve yağ içeriği yüksek tıbbi beslenme tedavisi programı ile birlikte karbonhidrat sayımı uygulaması kan glukoz düzeylerinin normal düzeylerde seyretmesine ve vücut ağırlığı kazanımına yol açmıştır. Kistik fibrozis ile ilişkili diyabetli hastalar diyabet ve KF konusunda uzmanlaşmış bir multidisipliner ekip tarafından izlenmelidir. Çocuk Endokrinoloji ve Çocuk Göğüs Hastalıkları Klinikleri arasında iyi bir iletişim olmalı ve hasta ideal olarak üç ayda bir bu klinikler tarafından izlenmelidir. Kistik fibrozis ile ilişkili diyabetli hastalar diyabet ekibinden ulusal standartları karşılayan bir diyabet eğitim programı almalıdır. Eğitim programı kapsamında hasta ve bakımından sorumlu kişiye insülin uygulamaları, hiperglisemi tedavisi, glukagon kullanımı da dahil olmak üzere hipoglisemi semptomları, önlenmesi ve tedavisi, kan glukoz ölçüm yöntemi, tıbbi beslenme tedavisi konuları anlatılmalıdır.

Çıkar çatışması - Conflict of interest: Yazarlar çıkar çatışması olmadı̆̆ını beyan ederler. - The authors declare that they have no conflict of interest. 


\section{KAYNAKLAR}

1. Kayani K, Mohammed R, Mohiaddin, H. Cystic fibrosisrelated diabetes. Frontiers in Endocrinology. 2018; 9:20:1-11.

2. Moran A, Pillay K, Becker D, Granados A, Hameed S, Acerini C.L. ISPAD Clinical Practice Consensus Guidelines 2018: Management of cystic fibrosis-related diabetes in children and adolescents. Pediatric Diabetes. 2018;19:64-74.

3. Türk Toraks Derneği. Kistik Fibrozis Tanı ve Tedavi Rehberi. Turk Thorac J. 2011;12(2):1-140.

4. O'Riordan SM, Dattani MT, Hindmarsh PC. Cystic fibrosisrelated diabetes in childhood. Hormone research in Paediatrics. 2010;73(1):15-24.

5. Moran A, Dunitz J, Nathan B, Saeed A, Holme B, Thomas W. Cystic fibrosis-related diabetes: current trends in prevalence, incidence, and mortality. Diabetes Care. 2009;32(9):1626-31.

6. Litvin M, Nwachukwu S. Cystic fibrosis related diabetes: a unique challenge in diabetes care. Missouri Medicine. 2016;113(5):384-9.

7. Moran A, Brunzell C, Cohen R. C, Katz M, Marshall B. C, Onady G. CFRD Guidelines Committee. Clinical care guidelines for cystic fibrosis-related diabetes: a position statement of the American Diabetes Association and a clinical practice guideline of the Cystic Fibrosis Foundation, endorsed by the Pediatric Endocrine Society. Diabetes Care. 2010;33(12):2697-708.

8. Koch D, Rainisio M, Madessani U. Presence of cystic fibrosis-related diabetes mellitus is tightly liked to poor lung function in patients with cystic fibrosis: data from the European Epidemiologic Registry of Cystic Fibrosis. Pediatr Pulmonol. 2001;32:343-50.

9. Nousia-Arvanitakis S, Galli-Tsinopoulou A, Karamouzis M. Insulin improves clinical status of patients with cystic-fibrosis-related diabetes mellitus. Acta Paediatr. 2001;90:515-9.

10. Bismuth E, Laborde K, Taupin P, Velho G, Ribault V, Jennane, F, et al. Glucose tolerance and insulin secretion, morbidity, and death in patients with cystic fibrosis. The Journal of Pediatrics. 2008;152(4):540-5.

11. Kolouskova S, Zemkova D, Bartosova J. Low-dose insulin therapy in patients with cystic fibrosis and early-stage insulinopenia prevents deterioration of lung function: a 30 year prospective study. J Pediatr Endocrinol Metab. 2011;24:454-99.

12. Moran A, Pekow P, Grover P. Insulin therapy to improve BMI in cystic fibrosis related diabetes without fasting hyperglycemia: results of the cystic fibrosis related diabetes therapy trial. Diabetes Care. 2009;32:1783-8.

13. Kaminski BA, Goldsweig B. K, Sidhaye A, Blackman S. M, Schindler T, Moran A. Cystic fibrosis related diabetes: Nutrition and growth considerations. Journal of Cystic Fibrosis. 2019;18:32-7.

14. Mohammed NH, Wolever TM. Effect of carbohydrate source on post-prandial blood glucose in subjects with type 1 diabetes treated with insulin lispro. Diabetes Research and Clinical Practice. 2004;65(1):29-35. 